\title{
The Second-Hand Goods Market: Trends and Challenges
}

\author{
Assist. Prof. PhD Yulia Hristova \\ University of Economics - Varna, Varna, Bulgaria \\ julia_hristova@ue-varna.bg
}

\begin{abstract}
Second-hand goods have been popular in their use since the time of bartering, and in the context of digitalization, they are gaining popularity among consumers around the world, especially the $X, Y$ and $Z$ generations. The resale market is a worthy alternative and a competitive threat to the new consumer goods one not only for economic consumer reasons but also on a social and ethical ones. Content analysis of research papers shows that studies related to the development of the second-hand goods market and the factors that motivate consumers to participate are therefore few and there is no systematized statistical information for this type market segment. Considering the rapid development of the resale market which is scarcely researched, this paper investigate some of the major trends in the second hand goods market, their causes and impact on retail in the digital society.
\end{abstract}

Keywords: second-hand goods market, retailing, competitive advantage

JEL Code: L100, M310; doi:10.36997/IJUSV-ESS/2019.8.3.62

\section{Introduction}

The market is the place where the exchange of utility for money happens. New goods of varying type and nature have the advantage of prestige and innovation, a plethora of selling points and the quality of their condition. The exchange of already used or pre-owned products however has had its own traditions since the time of bartering when an item that no longer had any use to its owner was swapped for something that was desirable for them but not for the other individual. Global studies show that digitalization not only helps maintain but also heightens the tendency towards re-commercialization which is a result of the new values and consumer behavior of generations $\mathrm{X}, \mathrm{Y}$ and $\mathrm{Z}$. The introduction of new trading formats, the consumer behavior of modern generations and development of social media, the Internet and environmental protection have led to a progressive rise of the second-hand goods market, especially in the last 40 years during which the purchase of these types of products became a worldwide phenomenon worth billions of dollars. For example, the global sales of second-hand apparel, shoes and clothing accessories are expected to increase from 24 billion USD in 2018 to 51 billion USD in 2023 (ThredUP, 2018). The global market of second-hand cars has reached 10.2 billion units during the third trimester of 2018 (Edmunds, 2018) while remaining traditionally larger than that of newer units (Hristova, 2018). In 2017 , the global market of pre-owned or used furniture comes to a sum of 29.3 billion USD and is predicted to keep growing with an annual rate of $6.4 \%$ until 2025 (Research Nester, 2017). The tendency displayed in the resale market of mobile phones on a global scale has reached 19 billion USD in 2017 with a prospect of expanding to 44 billion in 2026 (Persistence Market Research, 2018). The dynamic development of the second-hand goods market raises the questions of what the reasons behind consumer interest in it might be and what kind of role and influence it holds over the industry of newly produced goods.

Since it's a niche market segment (Williams \& Paddock, 2003), there is a lack of statistical information for the sales of second-hand goods. Its studies are few in number (Guiot \& Roux, 2010) and mostly geographically and product specific. They rely primarily on soft data while in Bulgaria there is almost no statistical data to be found. This is a prerequisite for the current paper to be methodologically based on content analysis of a variety of different documents, their logical and descriptive presentation, and for it to rely mainly on fragmented statistical data from different sources. Through the method of induction and deduction of their content, the primary trends of the second-hand goods market will become clear as well as the causes behind them and the challenges facing the retailing of second-hand goods and newly manufactured ones. 


\section{Development and importance of the second-hand goods market}

The retail trade of second-hand goods has had longstanding traditions and development. It is considered that people in European countries started purchasing and selling their used garments in the XIVth century, which was done due to poverty. The aspiration towards owning various goods, all different in nature at any point of time as well as the limitations in budget were the catalysts for the explosive development of trade with pre-owned and used products which dates back to the times of barter and continues to modern times

The second-hand goods retail market is considered to be a segment of the general commodity market which operates on the basis of every product bringing value to its owner regardless if it's first or second-hand. This gave rise to the second-hand goods market which separated itself from the first-hand one due to the fact that the products in questions were pre-owned or used at least once. As a rule, the fact that the purchase/sale of the item wasn't a primary act of the final consumer leads to its depreciation in value as well as a certain decrease in its quality. At the same time alongside the benefits of cheap pricing and the prospect of profit from its sale, the consumers are provided with a great choice of products of varying types and brands which are just as adequate as their newly manufactured counterparts. Plenty of markets appear as a result such as those for second-hand apparel, second-hand furniture, second-hand cars, second-hand books, machinery and electronics, old property domiciles with changed ownership and many other goods included with the exception of digital products due to licensing agreements (Downes, 2013). The development second-hand goods trade is advancing rapidly alongside the one of newly manufactured products which prompts a projection that the former will eventually pass the latter in the future (see fig. 1).

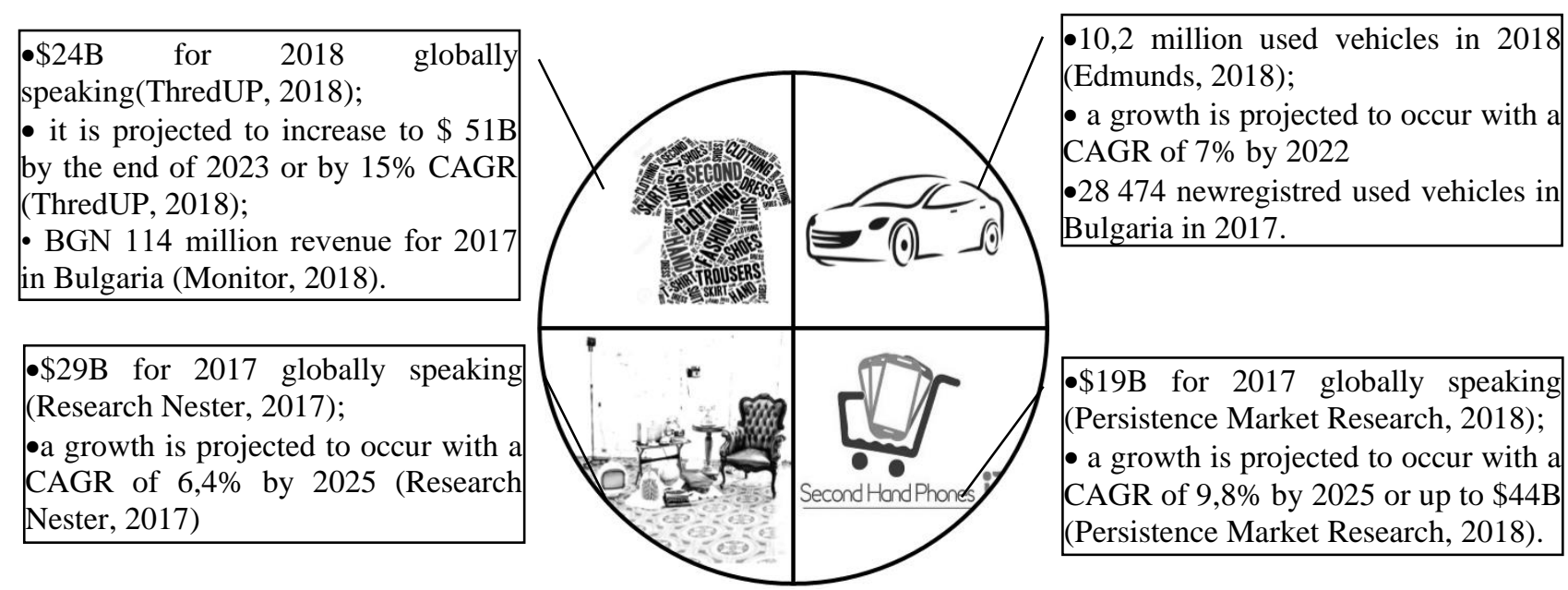

Figure 1. Sales of second-hand goods: clothes, cars, furniture, smartphones.

The trends in the global markets are an indicator for the increasing growth rate of the second-hand goods market which is stepping out of the shadow of the traditional first-hand products one. Studies reveal that in comparison to 2017 and 2018, for the multi-billion retail industry for second-hand goods - apparel, automobiles, furniture, smartphones - the next 5 years are projected to be with a global revenue increase of $6,4 \% \mathrm{CAGR}^{1}$ for second-hand furniture and an up to $15 \%$ surge in second-hand apparel. This development of second-hand goods market is going at a significantly higher rate than what's predicted for newly manufactured products. A good example would be that it's estimated for the CAGR of the global furniture market to be $5.1 \%$ (Grand View Research, 2018), in other words $1.3 \%$ lower than its second-hand counterpart, while in the fashion industry the CAGR of the secondary market is currently 7.5 times higher than that of the traditional

\footnotetext{
${ }^{1}$ Compound Annual Growth Rate
} 
market (ThredUP, 2018). In the newly manufactured automobile segment, this indication is estimated to be $4.79 \%$ annually (Market Reports World, 2019) which is 2.2\% lower than that of used cars. Anual smartphone sales on the other hand have grown with $4 \%$ less in comparison to the second-hand ones (Persistence Market Research, 2018). There is evidence that in Bulgaria secondhand apparel sales have reached 114 million BGN in 2017 (Monitor, 2018) as well as that newly registred used vehicles have reached 28 thousand units, 39\% of which were over 15 years old (Hristova, 2018). These facts pre-determine the future of retail trade with well-maintained secondhand goods as perspective and profitable.

Digital technologies and artificial intelligence are gaining popularity in the fourth stage of the industrial revolution. More than half of the planet's population uses the Internet, $42 \%$ of which are active social media users. According to a report from the 2017 World Economic Forum, technological advancements such as Internet being implemented on various items, autonomous vehicles, robotization, virtual and augmented reality, blockchain technologies will become available on the retail market in 10 years time (World Economic Forum, 2017). From trading in brick-andmortar retail establishments such as shops, farmers' markets, garage sales, supermarkets, the secondhand market has moved to the online sphere much like its first-hand equivalent. New Internet platforms were created for sale of such products alongside the newly manufactured ones (such as OLX.bg, Bazar.bg, Amazon.com, eBay.com etc.). Although the share of online purchases of cheaper second-hand goods is bigger, the sales of second-hand furniture and cars are also estimated to increase, the furniture's CAGR being 10,4\% (Research Nester, 2017). In accordance with the demands of the digitally active consumers, the traditional second-hand goods market has completely gone online, i.e. it supports sales by increasing its client base and its user awareness all over the world. This therefore reduced the transactional costs for deals on a global scale (Thomas, 2003) and helped increase the distribution and re-distribution of different types of goods to consumers living in different areas, from different social classes, all the while making the demand, purchase and resale of products more effective (Liao \& Chu, 2013). The development of digitization is a challenge for merchants of second-hand goods since the created platforms and sites are supposed to become competitive with those that offer new goods. Also the capacity of the online platform to guarantee the state of offered second-hand product as well as the reliability of its trader is questionable and might cause informational asymmetry (Ghose, 2009) which give rise to the demand for mandatory feedback and rating assesment of the provided merchandise and its vendor.

Through their demanding nature, desire to experience their purchase at their chosen time and place, the active digital generations $-\mathrm{X}, \mathrm{Y}$ and $\mathrm{Z}$ have changed the face of modern retailing by stimulating the development of multichannel and ominichannel sales, and through their behavior (constant demand for optimal commodities for a low price), they've stimulated the growth of the second-hand goods market (Thomas, 2003). Unlike the older generations, the young consumers are more flexible in their choice and less susceptible to risks related to using pre-owned or already used products such as: worn or unclean condition, poor quality, triviality etc. For example, in the world trade of second-hand apparel, $33 \%$ of consumers are millennials which adapt to buying used clothes 2.5 times quicker than other demographics. They keep changing their wardrobes constantly and make impulsive purchases, however they prefer to buy from vendors that are eco-friendly as well as prefer to save money by acquiring used apparel (ThredUP, 2018). A 2017 online survey for secondhand goods consumers suggests that young users (aged 18-29) order and sell used products much more often than older age groups, the main motive for selling being the profit and liberation from unneeded items (Statista, 2017). The digitally active generation is not loyal to any brand and would rather choose merchandise with the best uses at a minimal cost. This kind of behavior from the modern consumers and their unwillingness to leave the family nest, which also affects their loved ones, has led to an increase in competition between the manufacturers and traders of newly produced goods and the ones providing used products online and offline. The big global manufacturers are tasked with producing accessible channels for realization online such as well organized online platforms and brick-and-mortar shops which are convenient for consumers. At the same time they must follow competitive pricing policies and introduce timely discounts, otherwise 
they risk losing clients to the more competitive second-hand goods market. In turn, the attitude of the young consumers introduces its own set of challenges for the merchants of second-hand products, expressed in providing a good experience with the purchase of the item in online and offline channels which is adequate to the needs of the clients when it comes to comparing prices, as well as guaranteeing the quality of the merchandise, the name of its vendor, providing a large choice of big brand, highly sought products in a relatively new state and usability through which the user is educated about the available goods in the market.

The second-hand goods market plays a vital role in prolonging the use of a certain product through its re-sale, redistribution, recycling, renovating, new uses, which leads to the so called circular economy and sustainable development (Cherrier, et al., 2012; Young, et al., 2010) when the needs of consumers of different groups and social classes have been met. By fulfilling that role, the second-hand goods market originates from the first-hand one and at the same time replaces it. The two markets are interdependent and influence one another. By implementing their pricing, product and promotional policies, the merchants of newly manufactured products can affect the volume of the second-hand goods market. For instance, the manufactured limited edition luxury goods are sold at a higher price however in their successive re-sale on the secondary market, the profit of the reseller is also higher since after a certain period of time they are considered as Veblen goods (high rarity and unique). Vice versa, the resale of mass produced new products or of defective new goods destroys the profits of the reseller and that reduces the sales on the secondary market. Since it's a substitute for the first-hand product trade, the second-hand goods one severely undercuts the prices and sales of the primary market especially if the available merchandise is in good condition and with cheaper pricing. The dependability of the two types of goods - first and second-hand leads to an increase in competition between the markets for achieving sustainable competitive advantage in the conditions of changing consumer habits. The modern retailer reacts in a protective way towards the threat of being replaced by striving to win the competitive advantage by implementation an omnichannel trade parallel to new and used products and to realize policies for environmental protection.

The eco-consciousness of consumers and the global strategies for preserving the environment either reduce or change the manufacturing of new products, while the second-hand goods market is an alternative which alongside recycling and renovating has become preferred. The production of disposable utensils, bags and cotton swabs is a typical example of the realized threat born from the ecologic norms and ethical motives of consumers. According to the Directive of the European Parliament and of the council in regards to the reduction of the impact of certain plastic goods on the environment, the manufacturing of plastic plates, utensils, straws, balloon strings and cotton swabs which are convenient and cheap to make is prohibited until the year 2021, however they have to be substituted with products from environmentally-friendly materials such as cardboard, paper and wood. By doing this, consumers have stimulus to use tableware, bags and utensils for multiple use. That way the challenge that manufacturers and traders of new goods face is the decline of clientele. The fight with this challenges is expressed by various retailers in employing policies for stimulation of green initiatives (H\&M for instance collect old clothes from their customers which go either on re-sale as second-hand wares, or to be redesigned, or to be recycled); in realizing buy-back policies (new car dealers redeem the old vehicles of their clients on a massive scale after which they pay extra for the desired new car; the furniture giant IKEA decided to buy-in used furniture in Germany and offer a voucher of the value of the negotiated sales price so that the consumer can buy some new ones); or a stream of leasing campaigns which reduce the purchase price of first-hand merchandise for long-term use which in cases of operating lease is left remaining with the firm and is eventually sold on the secondary market.

The development of business with second-hand goods plays a positive role in the economy of a country by creating added value. The opening of points of sale for second-hand items sale (apparel, antique shops, automobiles, pawn shops etc.) has led to the increase in small and mediumsized undertakings which contribute to the GDP development of states, the opening up of new jobs, the establishment of contacts with other national and international enterprises through which consumer incomes is redistribute effectively and fairly. A study of DOXA related to the influence 
of second-hand economy in Italy has presented that sales constitute 1.1\% of GDP of the state in 2016 while online sales account for 7.1 billion Euro (Doxa, 2017). Amongst the large European countries, the one with the largest revenue from second-hand goods sales in brick-and-mortar shops was Germany which in 2016 has sold 3335,13 million dollars in used goods which is estimated to rise to 3570,08 million dollars by 2023 , while the lowest revenue was achieved by Greece $-11,15$ million dollars in 2016 and Slovenia - 3,08 dollars. The revenue from selling second-hand products in Bulgaria has more than doubled in 2016 compared to 2011 and shot up to 35,58 million dollars. That amount is expected to consistently continue its rising trend until 2023 when it would reach 49,47 million dollars (Eurostat., 2019). The tendency and opportunity for used goods to be repaired or converted into something else with its own design and purpose has fostered innovation in the economy and the creativity of its citizens which breeds entrepreneurial ideas with added value. The development of online platforms for second-hand products sale has increased consumer choice and experience of purchasing various by nature local and imported products. Effective competition between the first and second-hand market lead to their improvement, growth and completion.

\section{Drivers of development in the second-hand goods market}

The booming development of the second-hand goods market brings the question as to why a certain product which has already lost part of its characteristics and functionality after its first use would be considered desirable for a second and even third or fourth time (Guiot \& Roux, 2010). It is indisputable that the reasons for the existence of a second-hand goods market are rooted and are completely dependent on consumer behaviour and psychology. Studies of the motivation of consumers who are willing to buy second-hand products are heterogeneous; they use different methodologies and consist of different divisions of purchase factors (Herjanto, et al., 2016). Content analysis of some of them has allowed the drivers of consumer behaviour in the second-hand goods market to be separated in four basic groups: financial (economic), emotional (psychological), social, ecological and distributional (see fig. 2).

Financial (economic) drivers:

- a lower price purchase;

- the opportunity for bargaining;

- searching for a fair price;

-the reduction of alternatives and transactional costs;

- profit from the following resale;

- the effect of the increasing utility of the merchandise.

Social drivers:

-the influence of social media and the public;

-the redistribution of goods between consumers on a global scale;

-second hand goods have turned into a global fashion trend for people of different social statuses and classes;

- allow for accumulation of social contacts and creation of benchmark groups and communities.

-provide opportunity to get acquainted with new cultures and values.

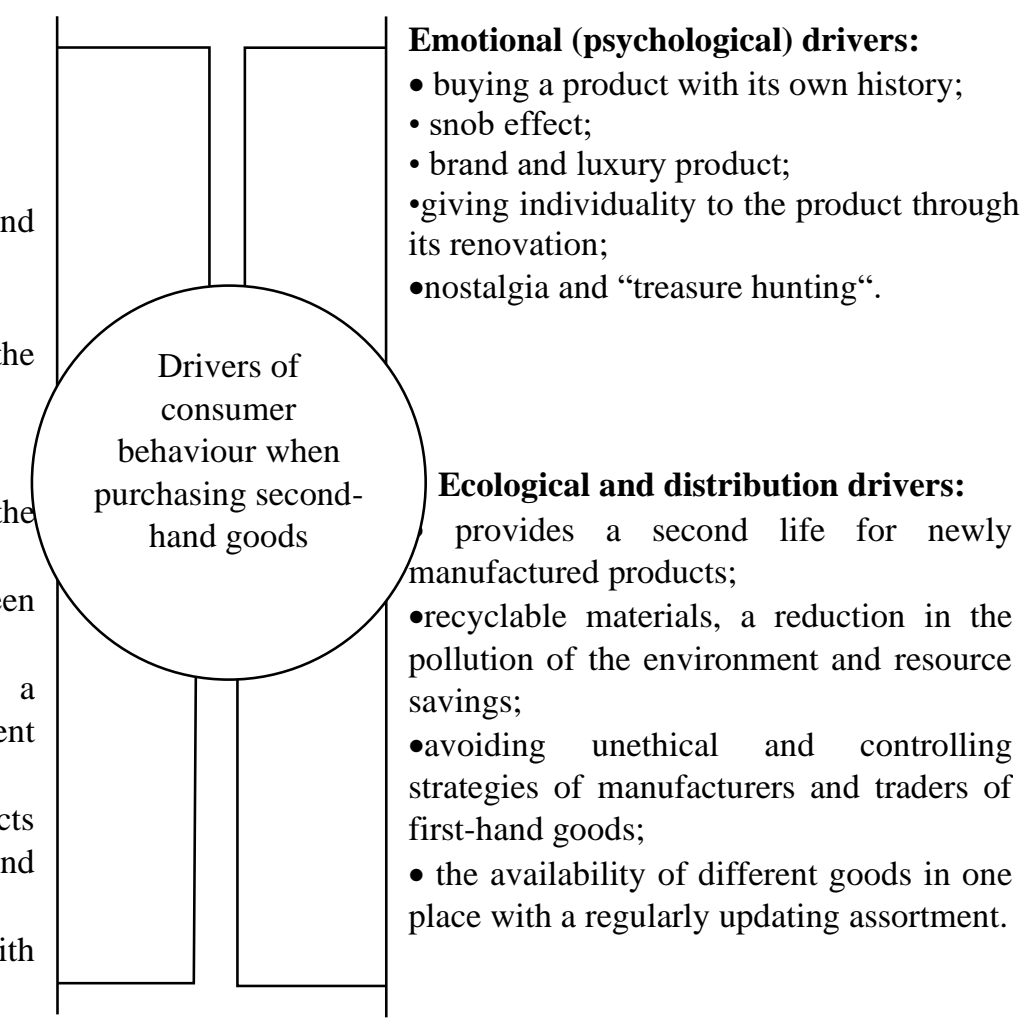

Figure 2. Drivers of consumer behaviour when purchasing second-hand goods 
Economic theory considers consumer behaviour as rational which pre-determines the gain of profit with minimal expenditures. This is the origin of one of the most often highlighted motivations for acquiring already used products and their subsequent resale - the financial motive or their relatively low price (Guiot \& Roux, 2010; Williams \& Paddock, 2003; Bardhi \& Arnould, 2005; Gullstrand Edbring, et al., 2016; Yan, et al., 2015; Ferraro, et al., 2016). E.g. 79\% of British (Scott, 2019) and $27 \%$ of Swiss respondents (Steffen, 2016, p.194) would consider buying second-hand furniture specifically because of the better price; the market trends for second-hand cars display the same reason for the purchase which applies even more for Bulgaria (Hristova, 2018); as for secondhand apparel, in 2018,66\% of Americans noted that they would buy such from a popular brand if it's of a lower price (ThredUP, 2018). Saving money is a motive for purchase for $60 \%$ of Italians as well (Doxa, 2017) as well as for $81.1 \%$ of Belgians (Gondola - Retail Facts \& Trends., 2019). The cost is the most important factor for buying second-hand apparel for Bulgarian consumers and according to the first of its kind study commissioned by the Association of recyclers and traders of second-hand clothes in Bulgaria (Monitor, 2018), 30\% out of 801 respondents consider them to be of better quality. A number of consumers also consider the gain in the opportunity of the pricing to be bargained for, to be agreed upon fairly and to reduce the alternative expenses when buying goods (Guiot \& Roux, 2010). The budget limit will turn the financial motive into a deciding factor which will tip the preference towards second-hand goods, however this factor is regarded as related to the rationality of the purchase which means that consumers will not spend what little money they have if the product is not useful. The cost and condition of the merchandise share the top spot with $88 \%$ out of 978 surveyed Americans as the top reasons for buying a used item, followed by the quality of said product (Statista Survey, 2017). The fact that the price is lower, increases the provided value for the consumer while the chance for it to be re-sold every other time (which is typical for goods which are more luxurious and big brand as well as unusable and less used such as baby clothes and accessories for example) brings additional profit and becomes another economic motive for purchase (e.g. for 33\% of surveyed Danes) (Avis, 2017). This way, the opportunity to buy a product, which is still functional and with good characteristics, which costs almost twice as less is a deciding driver for consumer behaviour in the second-hand goods market.

The originality, rarity, image, quality, uniqueness and history behind already used merchandise are a strong motive for its preference (Guiot \& Roux, 2010; Herjanto, et al., 2016). According to Swiss consumers of second-hand furniture, for example, they find new furniture to be boring $(20,9 \%)$ or discover that there is no item that suits them amongst the assortment $(15,4 \%)$ (Steffen, 2016). Unlike new market products, second-hand goods possess their own history, are often unique (one of a kind), can be remade or transformed into something different in accordance to the individual tastes of every consumer which will make them feel like they're standing out from the masses, i.e. the so called Snob effect ${ }^{2}$. As a result of these characteristics, a wide range of second-hand merchandise such as antiques, rare jewels and cars e.g. have a higher value than newly manufactured ones since they have their history behind them and are not a subject of modern production. Consumers are motivated to buy them since they feel nostalgia towards these types of goods (for example towards old electrical appliances, jewelry, furniture and apparel), others are led by the experience of "treasure hunting" after being presented with such a variety of products (Guiot \& Roux, 2010; Bardhi \& Arnould, 2005; Turunen \& Leipämaa-Leskinen, 2015). An opportunity for profit also arises from Veblen goods after their subsequent re-sale (O'Cass \& McEwen, 2004). Even if the second-class product is not rare, it's often of a brand that can be luxurious and its price significantly lower which would allow even consumers from a low social class to possess high brand goods through which they would build up their image in front of the public. For example the trend of purchasing second-hand cars indicates that the leaders sales-wise are the more luxurious brands (Hristova, 2018); young consumers view second-hand clothes as a ways to acquire style at a

\footnotetext{
${ }^{2}$ The effect of the snob makes its appearance when purchasing original and unique goods since the consumers want to differentiate themselves from everyone else who doesn't have access to such types of goods (Husic \& Cicic, 2009).
} 
reasonable price (Ferraro, et al., 2016; Yan, et al., 2015). The emotion and experience behind a purchase which has uniqueness, brand and style at a reasonable price is an important drive for consumer behavior at the second-hand goods market.

Individuals and their behavior are not isolated from the public, their social class and benchmark groups. The development of the Internet and social media has led to the appearance of an enormous amount of information related to different products, large choice of merchandise as well as experience exchange and communication between users. The social contacts of a certain consumer and his/her behavior in their community have left a trail that reflects his/her habits of use of second-hand goods. The influence of online social media when taking a decision on a purchase and reducing the risk of uncertainty is so strong that users listen to advice even from people who they're not acquainted with (Smith, et al., 2005). Since people are more likely to follow the behavior of their community, a large percentage of Americans e.g. between the ages of 18 and 37 adapt to the trends of second-hand goods purchases due to their concerns for the environment, the desire to save money and the prospect of earning profit from their re-sale (ThredUP, 2018). Young generations such as $\mathrm{Y}$ and $\mathrm{Z}$ most often change their wardrobe and consider unusable clothes as something to be recycled and re-sold (Monitor, 2018). The purchase and choice of merchants when it comes to second-hand cars, furniture and electric appliances in the digital world is also a result of research of sites, blogs, opinions and feedback in an online environment which is a significant social factor in regards to preference for pre-owned and used products. Social factors can also be a primary motive for purchase of second-hand products with a goal of demonstrating a certain lifestyle in public (Steffen, 2016), to create a shared social experience between the members of a specific community or for the individual to fit into said community. By increasing this trend of young consumers shopping online and exchanging their opinions, the social role of the public has surged on a global scale in regards to distrubution and re-distribution of goods that have not lost their properties and functionality, from the hands of people who do not need them to people who find them not only useful but also vital. For example, 39\% of the 2354 Danish respondents consider the sale of a used item an act which represents not wanting to throw away something that still functions, while $32 \%$ of them like the idea of having others benefit from second-hand merchandise (Avis, 2017); creating a new purpose for used goods is the main reason for $60 \%$ of surveyed Italians to order such (Doxa, 2017). In this view, the purchase of pre-owned merchandise has turned into a necessity and an expression of financial dependency in a global fashion trend which is used by people with varying social statuses and classes and therefore it guarantees the position of the individual in society.

A large number of researchers/scholars view the environmental awareness as a motive for purchase and preference for second-hand goods (Guiot \& Roux, 2010; Gullstrand Edbring, et al., 2016; Young, et al., 2010). Consumers are becoming increasingly concerned for the environment and their future as a part of the planet's ecosystem. The term circular economy was created which means lengthening the life cycle of products through sharing them for as long as possible as well as borrowing, re-using, repairing and recycling existing materials and products (Bekin, et al., 2007; Ha-Brookshire \& Hodges, 2009). Pollution of the environment from the malignant CO2 emissions, the overspending of resources and the large amount of waste is a prerequisite for disciplinary use of goods and the lack of mismanagement (Guiot \& Roux, 2010) which would in turn stimulate consumers towards purchasing still fit for use goods i.e. establishing ethical consumption. Studies of the reasons behind second-hand goods sales in Denmark indicate that $20 \%$ of the surveyed sell due to their concerns for the environment (Avis, 2017) while that percentage reaches $34,1 \%$ amongst Belgian consumers (Gondola - Retail Facts \& Trends., 2019). At the same time, there is no proof of direct correlation between environmental awareness and the use of second-hand goods (Yan, et al., 2015; Cervellon, et al., 2012; McNeill \& Moore, 2015) ${ }^{3}$, however this factor is viewed

\footnotetext{
${ }^{3}$ E.g. the purchase of second-hand cars with a petrol or diesel-fueled engine increases the volume of $\mathrm{CO}_{2}$ which contradicts ecological norms, however it is still a product preferred by the consumers due to economic reasons.
} 
to be in symbiosis with the desire of people to be frugal and calculating (due to purely economical reasons). The strategies of manufacturers and traders of first-hand products can also become a factor towards purchasing their second-hand counterparts due to their unethical nature or inadequate policies when it comes to the demands of user practices (misleading and aggressive commercial practices) as well as stripping the consumer from his right to choose. Through ads, policies of serving different markets, unfair price policies and strategies towards the consumer, contractual arrangements, "lemon" type of products coupled with other strategies, commercial agents try to guide the consumers and as a result they indirectly force them into searching for alternative channels of purchasing the desired product which happen to be online and offline markets of second-hand goods.

Drivers of consumer behaviour in the second-hand goods market are a serious prerequisite for the increasing influence of said market. Consumers might be led by several drivers when making a choice which are often a combination of each other as long as there is no contradiction (Guiot \& Roux, 2010) as well as choose with a financial or emotional driver as the dominant one. On the other hand the rational consumer takes into account the risks of already used products despite his/her motivation for purchase: functional, psychological, financial, physical, social and temporal which are heightened with the development of the digital market of second-hand goods. The preference of alternative merchandise to its newly produced counterpart in that respect rises, in accordance to the levels of perception of the type of risk in question. The less risk there is, the better for the consumer.

\section{Conclusion}

This paper presents the trend of the global development of the second-hand goods market as a phenomenon that transcends the geographic and social boundaries in society. As a result of the change in consumer habits of the young prejudice free generations, the purchase of already used merchandise has been transformed from a second-class act, which is inherent to people from lower social classes in geographically localized traditional shops, into a worldwide fashion trend related to buying something "cool" and "stylish". The primary drivers for the development of the second-hand goods market are the financial (economic), emotional and social ones which are rooted in the behavior of digitally active users who are seeking high brand, luxurious and unique products and most of all a good experience of the purchase at a convenient place, time and method, at a reasonable price. The increasing role of the second-hand goods market which is expressed in lengthening the life cycle of the products, creating added value for the economy, ensuring a sustainable and ethical development, gives rise to a competitive threat of replacement for manufacturers and traders of newly produced products and stimulates resale and the achievement of economic benefits in the secondary market. Consequently, this study takes into account the challenges for modern retailing towards keeping their first-hand goods attractive and authentic for people from younger generations, combining trading with both types of products online and offline. As for second-hand goods vendors there should be guarantees in regards to the characteristics of the merchandise offered and the image of their seller as well as development of attractive online platforms from which the global users can gather an educated and emotional experience when purchasing from a dynamic and a constantly growing assortment of products.

\section{References}

1. Avis, D. B., 2017. What are the main reasons for selling second-hand goods? Statista. Statista Inc.. Available at: https://www.statista.com/statistics/794935/reasons-for-selling-of-secondhand-goods-in-denmark/ [Accessed: 14/10/2019].

2. Bardhi, F. \& Arnould, E., 2005. Thrift shopping: Combining utilitarian thrift and hedonic treat benefits. Journal of Consumer Behaviour [Online], 4(4), pp. 223-233.

3. Bekin, C., Carrigan, M. \& Szmigin, I., 2007. Beyond recycling: 'Commons-friendly' waste reduction at new consumption communities. Journal of Consumer Behaviour, 6(5), pp. 271-286. 
4. Cervellon, . M., Carey, . L. \& Harms, T., 2012. Something old, something used: Determinants of women's purchase of vintage fashion vs second-hand fashion. International Journal of Retail \& Distribution Management, 40(12), pp. 956-974.

5. Cherrier, H., Szuba, M. \& Özçağlar-Tou, N., 2012. Barriers to downward carbon emission: Exploring sustainable consumption in the face of the glass floor. Journal of Marketing Management, October, 28(3-4), pp. 397-419.

6. Downes, L., 2013. Will We Get a Second-Hand Market for Digital Goods?. Available at: https://hbr.org/2013/03/will-we-get-a-second-hand-mark [Accessed: 27/09/2019].

7. Doxa, 2017. Leading drivers affecting the purchase of goods in second hand economy in Italy in 2016. Statista. Statista Inc.. Available at: https://www.statista.com/statistics/695087/drivers-forpurchasing-items-in-second-hand-economy-in-italy/ [Accessed: 14/10/2019].

8. Edmunds, 2018. USED CAR REPORT Q2018. Available at: https://qrgo.page.link/MvYBJ [Accessed: 27/09/2019].

9. Eurostat., 2019. Industry revenue of »retail sale of second-hand goods in stores « in Bulgaria from 2011 to 2023 (in million U.S. Dollars). Statista. Statista Inc.. Available at: https://www.statista.com/forecasts/390075/retail-sale-of-second-hand-goods-in-stores-revenuein-bulgaria [Accessed: 14/10/2019].

10. Ferraro, . S., Sands, S. \& Brace-Govan, J., 2016. The role of fashionability in second-hand shopping motivations. Journal of Retailing and Consumer Services [Online], Vol. 32, pp. 262268.

11. Ghose, A., 2009. INTERNET EXCHANGES FOR USED GOODS: AN EMPIRICAL ANALYSIS OF TRADE PATTERNS AND ADVERSE SELECTION. MIS Quarterly, 33(2), pp. 263-297.

12. Gondola - Retail Facts \& Trends., 2019. Reasons to buy second-hand goods in Belgium in 2018. Statista. Statista Inc.. Available at: https://www.statista.com/statistics/991307/reasons-to-buysecond-hand-goods-in-belgium/ [Accessed: 14/10/2019].

13. Grand View Research, 2018. Furniture Market Size, Share \& Trends Analysis Report By Material (Metal, Wood, Plastic, Glass), By End Use (Residential, Commercial), By Region (North America, Europe, APAC, MEA), And Segment Forecasts, 2018 - 2025, San Francisco: Grand View Research, Inc..

14. Guiot, D. \& Roux, D., 2010. A Second-hand Shoppers' Motivation Scale: Antecedents, Consequences, and Implications for Retailers. Journal of Retailing, 86(4), pp. 383-399.

15. Gullstrand Edbring, E., Lehner, M. \& Mont, O., 2016. Exploring consumer attitudes to alternative models of consumption: motivations and barriers. Journal of Cleaner Production [Online], Vol.123, pp. 5-15.

16. Ha-Brookshire, J. E. \& Hodges, N. N., 2009. Socially responsible consumer behavior? Exploring used clothing donation behavior. Clothing \& Textiles Research Journal, 27(3), pp. 179-196.

17. Herjanto, H., Scheller-Sampson, J. \& Erickson, E., 2016. THE INCREASING PHENOMENON OF SECOND-HAND CLOTHES PURCHASE: INSIGHTS FROM THE LITERATURE. JURNAL MANAJEMEN DAN KEWIRAUSAHAAN, 18(1), pp. 1-15.

18. Hristova, Y., 2018. Bulgarian Passenger Car Market: Dynamics and Perspectives. Albend, Bulgaria, 5-th International Multidisciplinary Scientific Conference on Social Sciences\&Art, Vol.5, Issue 1.4, pp. 61-68.

19. Husic, M. \& Cicic, M., 2009. Luxury consumption factors. Journal of Fashion Marketing and Management: An International Journal [Online], 13(2), pp. 231-245.

20. Liao, S. \& Chu, H., 2013. Influence of Consumer Online Resale Awareness on Purchase Decisions: A Mental Accounting Perspective. European Journal of Marketing, 47(10), pp. 15761597.

21. Market Reports World, 2019. South America Automotive Market - Growth, Trends, and Forecast (2019 - 2024), Market Reports World. 
22. McNeill, L. \& Moore, R., 2015. Sustainable fashion consumption and the fast fashion conundrum: fashionable consumers and attitudes to sustainability in clothing choice. International Journal of Consumer Studies, Vol. 39, pp. 212-222.

23. Monitor, 2018. Prouchvane: Kade i po kolko harchat balgarite za drehi. Available at: https://www.monitor.bg/bg/a/view/prouchvane-kyde-i-po-kolko-harchat-bylgarite-za-drehi147193 [Accessed: 27/09/2019].

24. O'Cass, A. \& McEwen, H., 2004. Exploring consumer status and conspicuous consumption. Journal of Consumer Behavior [Online], 4(1), pp. 25-39.

25. Persistence Market Research, 2018. Global Market Study on Refurbished and Used Mobile Phones: Herculean Growth in e-Waste to Make Used and Refurbished Phones a Prominent Choice among Consumers. Available at: https://www.persistencemarketresearch.com/marketresearch/refurbished-and-used-mobile-phones-market.asp [Accessed: 27/09/2019].

26. Research Nester, 2017. Off-the-Shelf Second Hand Furniture Market By Furniture Type Global Industry Insights \& Opportunity Evaluation 2017-2025. Available at: https://www.researchnester.com/reports/off-the-shelf-second-hand-furnituremarket/1230 [Accessed: 27/09/2019].

27. Scott, N., 2019. One man's trash...Is there an undiscovered market for second-hand furniture hidden in plain sight?. Available at: https://medium.com/street-voice/one-mans-trash13146abafee [Accessed: 27/09/2019].

28. Smith, D., Menon, S. \& Sivakumar, K., 2005. Online Peer and Editorial Recommendations, Trust, and Choice in Virtual Markets. Journal of Interactive Marketing, 19(3), pp. 15-37.

29. Statista Survey, 2017. If you buy used goods, which item attributes are particularly important to you?. Statista. Statista Inc.. Available at: https://www.statista.com/statistics/730585/importantitem-attributes-for-purchasing-used-goods-us/ [Accessed: 14/10/2019].

30. Statista, 2017. Re-Commerce in the U.S. 2017 report, Statista Inc..

31. Steffen, A., 2016. Second-hand consumption as a lifestyle choice. Available at: https://www.verbraucherforschung.nrw/sites/default/files/201710/DOI\%2010.15501\%20978-3-86336-918-7_16-steffen.pdf [Accessed: 27/09/2019].

32. The CAF Global Alliance, 2018. CAF World Giving Index 2018. Available at: https://www.cafonline.org/docs/default-source/about-uspublications/caf_wgi2018_report_webnopw_2379a_261018.pdf [Accessed: 27/09/2019].

33. Thomas, V. M., 2003. Demand and Dematerialization Impacts of Second-Hand Markets. Reuse or More Use?. Journal of Industrial Ecology, 7(2), pp. 65-78.

34. ThredUP, 2018. ThredUP's Annual Resale Report 2018. Available at: https://cf-assets-tup.thredup.com/resale_report/2018/2018-resaleReport.pdf [Accessed: 27/09/2019].

35. Turunen, L. \& Leipämaa-Leskinen, H., 2015. Pre-loved luxury: identifying the meaning of second hand luxury possessions. Journal of Product \& Brand Management [Online], 24(1), pp. 57-65.

36. Williams, C. C. \& Paddock, C., 2003. Explaining Informal and second-hand goods. The International Journal of Sociology and Social Policy, 23(12), pp. 95-110.

37. World Economic Forum, 2017. Sharping the Future of Retail for Consumer Industres. Available at: http://www3.weforum.org/docs/IP/2016/CO/WEF_AM17_FutureofRetailInsightReport.pdf [Accessed: 27/09/2019].

38. Yan, R., Bae , S. Y. \& Xu, H., 2015. Second-hand clothing shopping among college students: the role of psychographic characteristics. Young Consumers [Online], 16(1), pp. 85-98.

39. Young, W., Hwang, K., McDonald, S. \& Oates, C. J., 2010. Sustainable Consumption: Green Consumer Behaviour When Purchasing Products. Sustainable Development, 18(1), pp. 20-31. 